\title{
ISLAMIC LAW POLITICS IN THE CONTEMPORARY ERA (REVEALING THE STRUGGLE FOR THE POSITIVIZATION OF ISLAMIC LAW IN INDONESIA)
}

\author{
Muhazir \\ Institut Agama Islam Negeri Langsa, muhazir@iainlangsa.ac.id

\begin{tabular}{|l|l|l|}
\hline Accepted: $2021-06-30$ & Revised: 2021-07-11 & Published: 2021-07-31 \\
\hline
\end{tabular} \\ (c) (i) () \\ C 2021 by the authors. Submitted for possible open access publication under the terms and conditions \\ of the Creative Commons Attribution (CC-BY-SA) license (https://creativecommons.org/licenses/by-sa/4.0/) \\ DOI : 10.30983 /alhurriyah.v6i1.3956
}

\begin{abstract}
This paper will discuss the politics of Islamic law until now, which still leaves debates between pros and cons parties, this debate is based on differences in views between secular Islamic groups and traditionalist, plus global political conditions increasingly influence the direction of Indonesian government legal policies. Library research is the method used in this paper, the legal policy approach and statute approach are used to analyze data found in various literature. The results of this study indicate that the struggle for the positivists of Islamic law in Indonesia is still reaping polemics, these polemics are based on three things; first, differences in understanding of the relationship between religion and state; second, the contemporary Indonesian political system is influenced by western politics; third, liberalism and communism have helped to hinder the positivists process of Islamic law in Indonesia.
\end{abstract}

Keywords: Politics, Islamic Law, Positivists

\begin{abstract}
Abstrak
Tulisan ini akan mendiskusikan tentang politik bukum Islam bingga saat ini yang masib menyisakan perdebatan antara pibak pro dan kontra, perdebatan ini didasari oleb perbedaan pandangan antara kelompok Islam sekuler dan Islam tradisionalis, ditambablab lagi dengan kondisi politik global semakin mempengarubi arah kebijakan bukum pemerintah Indonesia. Library research merupakan metode yang digunakan dalam tulisan ini, pendekatan legal policy dan statute approach dugunakan untuk menganalisis data yang ditemukan dalam berbagai literatur. Hasil penelitian ini menunjukan bahwa pergulatan positivisasi bukum Islam di Indonesia masih menuai polemik, polemik tersebut didasari oleh tiga hal; pertama, perbedaan pemahaman tentang bubungan antara agama dan negara; kedua, sistem politik indonesia masa kontemporer dipengarubi oleh politik barat; ketiga, paham liberalisme dan komunisme turut menghambat proses posotivisasi bukum Islam di Indonesia
\end{abstract}

Kata Kunci: Politik, Hukum Islam, Positivisasi

\section{INTRODUCTION}

In the contemporary period of the $20^{\text {th }}$ century after the end of World War $\mathrm{II}^{1}$, Islamic law increasingly has an attraction for European legal experts, this interest is proven by the many Islamic studies conducted by western researchers.
Countries that make Islamic law as state law become a special attraction for research because, for them, the law is understood through empirical studies and apart from the theological aspect, which in the end resulted in a school of law, such as the schools of natural law ${ }^{2}$, legal history ${ }^{3}$,

\footnotetext{
${ }^{1}$ Amin Mudzakkir, "Islam Dan Politik Di Era Kontemporer," Epistemé: Jurnal Pengembangan Ilmu Keislaman 11, no. 1 (2016): 32, https://doi.org/10.21274/epis.2016.11.1.31-48.
}

2 Syofyan Hadi, "Kekuatan Mengikat Hukum Dalam Perspektif Mazhab Hukum Alam Dan Mazhab Positivisme Hukum," Legality: Jurnal 
positivism $^{4}$, realism ${ }^{5}$, and utility ${ }^{6}$. Each has its concept in understanding the law. In contrast to Islamic products that are directly related to theological aspects, so that the belief in applying God's law is felt more comprehensively by the Moslem community.

For a democratic country, the law becomes an identity to show that legal certainty is protected by the state. Democracy is understood as the "best" political system to achieve justice for the people, following the democratic concept that government is from the people, by the people, and for the people. Democracy is also influenced the political system because the concept of the democratic state is closely related to the concept of trias politica. Trias politica provides legislative, judicial and executive roles to run the wheels of government with its absolute authority ${ }^{8}$. For a democratic country, the legislature is the main mobilizer to maintain justice and

Ilmiah Hukum 25, no. 1 (2018): 88-89, https://doi.org/10.22219/jihl.v25i1.5992.

3 Zainal Asikin, Mengenal Filsafat Hukum (Yogyakarta: Penerbit Andi, 2020), 117.

4 Sri Wahyuni, "Pengaruh Positivisme

Dalam Perkembangan Ilmu Hukum dan Pembangunan Hukum Indonesia," Al-Mazabib: Jurnal Pemikiran Hukum 1, no. 1 (2012): 3.

${ }^{5}$ Asikin, Mengenal Filsafat Hukum.153

6 Suri Ratnapala, Jurisprudence: An Introduction. (Leiden: Cambridge University Press, 2009).30

7 Muhammad Hanafi, "Kedudukan Musyawarah Dan Demokrasi Di Indonesia," Jurnal Cita Hukum 1, no. 2 (2016): 235, https://doi.org/10.15408/jch.v1i2.2657.

8 NE Mathebula and PH Munzhedzi, "Trias Politica for Ethical Leadership and Good Governance: Praxis of Checks and Balances in the South African Context," Bangladesh E-Journal of Sociology 14, no. 2 (2017): 8. legal equality through legal products, this is where the initial process of positivizing Islamic law is carried out by adopting the laws and values contained in Islam.

The political dynamics of Islamic law in the contemporary era are heating up when they get resistance from those who reject the application of Islamic law. The agreement on the application of Islamic law occurs when the applied law is directly related to theology, such as the law of zakat, marriage, hajj, waqf, even recently the Islamic economy has also taked part the banking system in the world. Politics and Islam in contemporary Indonesia have at least two faces between political Islam and cultural Islam9. Political Islam is based on the desire to include Islamic values in the state, while cultural Islam is based on Islamic traditions that do not include themselves in state politics. In Indonesian history, Masyumi's (Council of Indonesian Muslim Associations) presence is a representation of an Islamic political party, while the Islamic Union (Serikat Islam) is the first organization that represents cultural Islam with the largest number of members ${ }^{10}$.

Based on a glimpse of political history in Indonesia, Moslems have a great influence in colouring the government system in Indonesia. Moreover, Indonesia is a democratic country, the legislation of Islamic law can only be done through

9 LL Saefudin Zuhri, "Dinamika Islam Politik Dan Islam Kultural di Indonesia," JURNAL INDO-ISLAMIKA 8, no. 1 (2020): 51, https://doi.org/10.15408/idi.v8i1.17541.

10 Mudzakkir, "Islam Dan Politik Di Era Kontemporer."41 
politics. In the contemporary world, Islam is one of the competing ideologies in world politics, Islam seeks to achieve strategic positions in government. Islam is looking for its identity in the political arena which was once understood as a sacred identity turned into a profane identity, debates often occur between Moslems themselves, namely traditionalist Islam and modernist Islam. The political orientation of modernist Moslems is to give an understanding that Islam is not only involved in the theological world which is sacred, but Islam also participates in movements in the public sphere that are political, although at the beginning of the emergence of Islamic parties they did not have a place in the world community, because they were faced with socialist, liberalist, and communist political parties. As in Indonesia, at the beginning of the emergence of Islamic parties, Masyumi had to share with socialist and communist parties ${ }^{11}$. In contrast to Turkey after the collapse of Kemal's secular ideology, in 2002 the Islamic party won ${ }^{12}$.

Research conducted by Muhammad Ainun Najib ${ }^{13}$, Siti Maheasy ${ }^{14}$, Ahmad

11 Muhammad Ainun Najib, "Politik Hukum Formalisasi Syariat Islam Di Indonesia," IN RIGHT: Jurnal Agama dan Hak Azazi Manusia 6, no. 2 (2017): 163.

12 Vedi R. Hadiz, "No Turkish Delight: The Impasse of Islamic Party Politics in Indonesia," Southeast Asia Program Publication at Cornell University Press 92 (2011): 1-18, https://doi.org/10.5728/indonesia.92.0001.

13 Najib, "Politik Hukum Formalisasi Syariat Islam Di Indonesia.”164

14 Siti Mahmudah, "Politik Penerapan Syari'at Islam Dalam Hukum Positif di Indonesia
Hafidh $^{15}$, Muhammad Irham ${ }^{16}$, shows that the politics of Islamic law in Indonesia is strongly influenced by the interest of the rulers. Not only that, even Islamic law has received less response from the Indonesian Islamic community, even though the majority of the Indonesian population is Moslem. However, some of them have different views about the state and Islamic law. Even at the theoretical level, Islamic scholars still have different views about Islamic law itself ${ }^{17}$.

This paper is a literature study by examining the results of research related to the study of this paper. The legal policy approach ${ }^{18}$ and legislation (statute approach) ${ }^{19}$ become the basis of analysis to answer the problems surrounding contemporary Islamic legal politics. The question in this research is how the struggle for positivization of Islamic law occurs in contemporary Indonesia? The purpose of this paper is to analyze the political dynamics of contemporary Islamic law and

(Pemikiran Mahfud MD)," AL-'ADALAH 10, no. 4 (2012): 12.

15 Ahmad Hafidh, "Pertarungan Wacana Politik Hukum Islam di Indonesia," Yustisia 3, no. 3 (2014): 19.

16 Muhammad Irham, "Perkembangan Politik Hukum Islam pada Masa Klasik dan Kontemporer," Madania: Jurnal Hukum Pidana dan Ketatanegaraan Islam 9, no. 1 (2019): 85-98.

17 Mohamad Abdun Nasir, "Wacana Syariat Kontemporer di Barat: Studi Pemikiran Wael B. Hallaq dan M. Barry Hooker," ULUL ALBAB Jurnal Studi Islam 18, no. 1 (2017): 1-4, https://doi.org/10.18860/ua.v18i1.4268.

18 Abdul Manan, Dinamika Politik. Hukum Di Indonesia (Jakarta: Kencana, 2018), 9.

19 Made Pasek Diantha, Metodologi Penelitian Hukum Normatif dalam Justifikasi Teori Hukum (Jakarta: Prenada Media, 2016).156 
the struggle for positivization of Islamic law in Indonesia.

\section{THE CONTEMPORARY ISLAMIC LAW POLITICAL STRUGGLE}

The journey in institutionalizing Islamic institutions has gone through a long process, it requires recognition from the state to make Islamic law part of state law, which produces regulation with Islamic nuances. However, Islamic law will be able to become a source of law that has permanent legal force if it has been reduced to state law. This is the basic capital for voicing legal reform and incorporating Islamic law into state law. The condition of the people with their Islamic character is very influential in the development of laws and institutions in Indonesia because in essence regulations are made to serve the people, following the legal needs of the people, as Eugen Ehrlich said that law is based on social facts that depend on the social rather than the state. According to him, the law can only be understood from a sociological perspective. Ehrlich added that the law had lived and developed before state law existed, some rules such as marriage, business and other social institutions existed before state law. Therefore, the law that lives in society must be positioned on a par with state law ${ }^{20}$.

Islam entered Indonesia in the $7^{\text {th }}$ or $8^{\text {th }} \mathrm{AD}$, but it has not spread thoroughly in the territory of Indonesia, because it does not yet have the power to spread Islam. When the fall of Baghdad was due to the

20 Werner Menski, Comparative Law in a Global Context the Legal Systems of Asia and Africa (London: Cambridge University Press, 2006), 92-93. attack by Hulagu's army, the Baghdad merchants shifted their activities to Asia. This is where the religion of Islam brought by the merchants began to spread in several parts of Asia. The process of spreading begins with marrying indigenous people and converting them to Islam. This is very influential in the process of spreading Islam slowly by surely ${ }^{21}$.

The rapid development of Islam in Indonesia has resulted in the formation of Islamic traditions in the activities of some Indonesian people, by applying the principles of Islamic law and various regulations based on Islamic law enough to colour the culture of Indonesian society, resulting in acculturation between culture and Islam ${ }^{22}$, which previously carried out regulations contrary to Islam with the "law of the jungle" turned into an Islamic culture that is relevant to Islamic provisions and based on justice ${ }^{23}$.

The development of Islam is getting bigger and bigger, $90 \%$ of Indonesian people are Moslem and Indonesia's population is 200 million $^{24}$. Thus, Islamic education is taught in Surau (Islamic assembly building), where the youths usually gather. This activity developed and

21 Ahmad Sukardja, Piagam Madinab Dan UUD NRI 1945 (Jakarta: Sinar Grafika, 2012).66

22 M. H. Hooker, Adat Law In Modern Indonesia (New York: Oxford University Press, 1978), 6.

23 John R Bowen, Islam, Law, and Equality in Indonesia an Antbropology of Public Reasoning (Cambridge, UK; New York, NY: Cambridge University Press, 2003), 13-14.

24 Lili Romli, "Partai Islam dan Pemilih Islam di Indonesia," Jurnal Penelitian Politik 1, no. 1 (2016): 29, https://doi.org/10.14203/jpp.v1i1.370. 
expanded in Nusantara, even many young people went to Mecca to study Islam, this condition was also seen after the independence of the Republic of Indonesia in 1945. With the presence of the majority of Moslems in Indonesia, it can provide enormous potential to encourage the government to form Islamic regulations and institutions. Not only that the presence of Moslems in Indonesia is fertile ground for the enforcement of Islamic law ${ }^{25}$, such as in Aceh, which applies Islamic law.

After the independence of the Republic of Indonesia, many figures fought to uphold Islam. Well-known figures such as Ahmad Sanusi, Wahid Hasyim, Kahar Muzakkir advocate that the Indonesian state ideology is relevant to the Islamic ideology ${ }^{26}$. We can see that the contents of the 1945 Constitution do not contradict Islamic teachings, as well as the principles of Pancasila. This condition illustrates that substantively Indonesia adheres to Islamic values.

The development of Islam in Indonesia affects the legal system in Indonesia. According to Abdul Manan, Islamic law is currently in three places ${ }^{27}$, first, it is spread in fiqh books that have been written by previous scholars. Until now, the book of fiqh (arabic script) is still the reference for religious courts in Indonesia, the book of figh is still the main reference in exploring Islamic law and

\footnotetext{
25 Jawahir Thontowi, Islam, Politik Dan Hukum (Yogyakarta: MADYAN Press, 2002), 28.

${ }_{26}$ Sunanto, Sejarah Peradaban Islam Indonesia, 53.

${ }^{27}$ Abdul Manan, Reformasi Hukum Islam Di Indonesia (Jakarta: Raja Grafindo Persada, 2006), 11.
}

solving problems in religious courts. The majority of figh books used are Shafi'i schools; second, contained in state laws and regulations such as the Marriage Law, KHI, Waqf and other regulations; third, it is contained in the judge's decision which has taken the form of jurisprudence.

The majority of Moslem communities in Indonesia are more comfortable implementing Islamic law in terms of private law rather than positive law. This makes the government must form laws and institutions that can protect the legal culture that develops in society. This aims to create legal unity to create an orderly legal order. Even before Indonesia's independence, Islamic institutions were formed, such as the "Seurambi" court, the penghulu (district level judge) and the penghulu agung (royal level judge ${ }^{28}$.

During the Dutch colonial period, several institutions were formed to oversee the legal aspirations of the indigenous people $^{29}$, such as the establishment of a priesterraad or raad agama or also known as the religious courts in Java and Madura ${ }^{30}$. To defend its colonies, the Dutch also tried to embrace the socio-religious people of Indonesia. This can be seen with the issuance of Staatsblad Number 22 of 1820. Article 13 of the Staatsblad states that the regent must pay attention to religious issues

28 Erfaniah Zuhriah, Peradilan Agama Indonesia: Sejarah, Konsep, Dan Praktik Di Pengadilan Agama (Malang: Setara Press, 2014), 62-63.

${ }^{29}$ Ratno Lukito, "Islamic Law And Adat Encounter: The Experience Of Indonesia," Institute of Islamic Studies McGiH University, 1997, 35-36.

30 A. Basiq Djalil, Peradilan Agama Di Indonesia:, 1st ed. (Jakarta: Kencana, 2006), 17. 
and maintain religious processes that take place following Javanese customs, such as in matters of marriage, inheritance and so on $^{31}$.

Post-independence, to ensure and avoid ambiguity in the implementation of the law. The position of Islamic law in the Republic of Indonesia is explicitly stated in Article 29 of the 1945 Constitution which states that the state based on one Godhead guarantees that each resident worships based on their respective religions and beliefs. According to Hazairin, the fundamental rules in this article are ${ }^{32}$; first, in the Republic of Indonesia, there may not be or may not apply laws that are contrary to religious principles for adherents of their religion; second, the state is obliged to implement the sharia of all religions in Indonesia.

The practice of implementing Islamic law that has been practised by the Moslem community has received appreciation from the government. Therefore, the government established several Islamic institutions/agencies to control the legal process, particularly Islamic law in Indonesia, among other; (1) Religious Courts/Sharia Courts; (2) Departemen agama (Religion Department); (3) KUA (Office of Religious Affairs); (4) BAZNAS (National Amil Zakat Agency); (5) MUI (Indonesian Ulema Council).

Each of these institutions has its respective duties that have been regulated

\footnotetext{
31 Zuhriah, Peradilan Agama Indonesia, 79.

32 Akhmad Mujahidin, Aktualisasi Hukum Islam: Tekstual Dan Kontekstual, 1st ed. (Pekanbaru: Program Pascasarjana, UIN Suska Riau, 2007), 190.
}

by the government in the form of laws and regulations. Each of these tasks is carried out under applicable regulations. To avoid confusion in reducing Islamic law to state law, the Ministry of Religion, MUI and Islamic organizations have a role in controlling the process of forming and implementing these regulations so that there is no conflict between state law and Islamic law.

\section{ISLAMIC LAW POLITICS: THE POSITIVATION OF ISLAMIC LAW COMPROMISE BETWEEN THE NETHERLANDS AND INDONESIAN GOVERNMENTS}

The first time the Dutch came to Indonesia was in the $17^{\text {th }}$ century to look for spices, but the natural wealth owned by the Nusantara at that time had changed the intention of the Dutch, from trading activities to colonizing. In the early colonial period, the Dutch recognized the existence of Islamic law. This legal system is considered a living law in society. If they disturb the existence of that norm, then, it also means that they disturb the society which will lead to rebellion ${ }^{33}$.

After a long silence without interfering in the religious courts, the Dutch finally issued a policy through the VOC Dutch trading office (1602-1880). On May 2, 1760, the Resolutie der indesche Reegering was issued, which is a provision for the enactment of a set of marriage laws and inheritance laws according to Islamic law used in VOC courts for Indonesians.

33 Abdul Manan, Aneka Masalah Hukum Perdata Islam Di Indonesia, 1st ed. (Jakarta: Kencana, 2006), 291-292. 
This resolution is known as the Compendium Freiyer which can be said to be the first form of legislation in Islamic law ${ }^{34}$. In addition, the Dutch also issued Cirbonsch Rechboek, which was compiled from the proposal of the Resident of Cirebon, Mr. P.C Hosselar (1757-1765) with the title Compendium der Van Voornaamste Gotrekken uit het Mohammedaansch Wetboek Morgharrear. This book was compiled for Landraad Semarang (1750) based on Imam al-Safi'i's al-Mubarrar book. Substantively the book made by the Dutch contains Islamic criminal law and custom ${ }^{35}$.

Policies related to the legislation of Islamic law by the Dutch were influenced by the Receptie in Complexu theory proposed by Prof. Dr. Lodenwijk Willem Christian Van den Berg (1845-1927) ${ }^{36}$. He said that for Moslems, Islamic law is fully applied because they have embraced their religion even though in practice there are deviations. The Dutch also made efforts to enforce Islamic inheritance and marriage laws by Dutch judges with the help of Islamic qadhis. Van den Berg positioned Islamic law on a par with other legal systems. This theory also has implications for the existence of Islamic institutions, for example on December 1, 1835, the Dutch issued Staatsblad No. 58 of 1835 which recognized the existence of the Religious

34 Mahsun Fuad, Hukum Islam Indonesia: Dari Nalar Partisipatoris Hingga Emansipatoris, 1 st ed. (Yogyakarta: LKiS, 2005), 50.

35 A. Rahmat Rosyadi and H. M. Rais Ahmad, Formalisasi Syariat Islam Dalam Perspektif Tata Hukum Indonesia, 1st ed. (Bogor: Ghalia Indonesia, 2006), 75.

${ }^{36}$ Zuhriah, Peradilan Agama Indonesia. 82.
Courts (PA) in Batavia ${ }^{37}$. However, the Dutch still limited the PA's authority to only adjudicate civil cases, while criminal cases were handed over to Landraad. At first, the Dutch legal politics was quite favourable to the position of Islam at least until the end of the $19^{\text {th }}$ century with the issuance of Staatsblad Number 152 of 1882 which regulates and recognizes the existence of religious courts in Java and Madura.

This condition did not last long, the Dutch government was concerned about the development of Islamic law in Indonesia which could affect the stability of the life of Moslems in Indonesia. This condition is also felt to threaten their position in Indonesia. Responding to this phenomenon, the Dutch pioneered by Christian Snouck Hurgronje (1857-1936) opposed the Receptie in Complexu theory and made efforts to narrow the validity of Islamic law by introducing the Receptie theory $^{38}$. According to them, the law that applies to indigenous people is their respective law (customary law). Islamic law can apply if it has been accepted (accepted and implemented) by customary law. Thus, it is customary law that determines the strength of Islamic law. This theory directly kills the existence of Islamic law in Indonesia ${ }^{39}$.

After Indonesia's independence, although the transitional regulations stated that the old law was still valid as long as it did not

${ }^{37}$ The name of Jakarta during the Dutch colonial period

38 Fuad, Hukum Islam Indonesia. 52.

39 Imam Sudiyat, Asas-Asas Hukum Adat Bekal Pengantar (Yogyakarta: Liberti, 1991), 3. 
conflict with the 1945 Constitution, all Dutch regulations based on the receptie theory were no longer valid because their spirit was contrary to the 1945 Constitution. The receptie theory must be removed because it contradicts the Koran and Sunnah. Hazairin calls the receptie theory as the wrong theory. So Hazairin developed a theory known as the exit receptive theory ${ }^{40}$.

Besides Hazairin, another figure who also opposes the receptie theory is Sayuti Thalib who wrote the receptie a centrario theory: the relationship between customary law and Islamic law. This theory contains the idea that customary law only applies if it does not conflict with Islamic law. Through this theory, all regulations based on receptie theory are removed ${ }^{41}$.

In the matter of worship, the Dutch East Indies government issued many regulations, including; regulates waqf in BS Number 6196 dated June 31, 1905, concerning instructions to regents in Java and Madura to list Islamic houses of worship, BS Number 12573 dated June 4, 1931, concerning instructions to regents in Java and Madura to identify Islamic houses of worship of waqf or not, Circular No. 13390 dated December 24, 1934, regarding

40 The main ideas of the receptie exit theory are: first, that the receptie theory does not apply and is out of the Indonesian state system; second, that according to the 1945 Constitution, Indonesia must immediately establish a national law based on religious law; third, that religious law that entered Indonesia became national law, not only Islamic law based on Pancasila.

41 Mardani, Hukum acara perdata peradilan agama \& mabkamah syar'iyah (Jakarta: Sinar Grafika, 2009), 3. the role of the regents in resolving disputes regarding the place for Friday prayers, and Circular No. 1273/A dated May 27, 1935, as contained in the Bijblad No. 13480 of 1935 regarding the waqf procedure. All of this proves that the awareness of some Indonesian people in practising Islamic law. Thus, disturbing the Dutch government to formalize Islamic law ${ }^{42}$.

After independence, three legal systems existed in Indonesia. (1) Islamic Legal System; (2) the Colonial Legal System; (3) Customary Law System. The intersection between one of the above legal systems and other legal systems sometimes creates a conflict. Even this conflict can be considered unnatural because this conflict was engineered by the Dutch in breaking the unity of the Indonesian people. Based on this phenomenon, Indonesia is trying to bridge the gap so that this conflict will be eroded with the times ${ }^{43}$. And the development of Islamic law into a product of legislation then depends on national policies issued by the state founders.

Islamic law legislation has shown significant developments, one of which is the emergence of Law no. 22 of 1946 which was ratified by Law Number 32 of 1954 which regulates the registration of marriages, divorces and reconciliations. This law then affected the separation of the duties of the penghulu from the head of the court which had previously been one task.

42 Juhaya S Praja, Perwakafan Di Indonesia (Bandung: Yayasan Piara, 1997), 32.

43 Busthanul Arifin, Pelembagaan Hukum Islam Di Indonesia: Akar Sejarah, Hambatan, Dan Prospeknya, 1st ed. (Jakarta: Gema Insani Press, 1996), 34. 
Then came Law Number 19 of 1948 concerning the Structure and Powers of the Judiciary and Prosecutor's Office which states that the religious courts are one of the special courts in Indonesia. However, the existence of Religious Court has not shown a significant change. Its authority is still mixed with the District Court. In addition, there are not many regulations specifically for Moslems that are used as references in making decisions.

There were not many processes of positivization of Islamic law in law due to the unstable political condition of Indonesia at that time, the rules that were applied were also temporary. In addition to attacks from Allied forces, Indonesia also faced rebellions that threatened the stability of the nation, such as the PKI (The Communist Party of Indonesia) rebellion. However, it should be noted that the increasing awareness of the Moslem community to practice Islamic teachings in everyday life, such as in matters of marriage and inheritance, has proven that the tendency to enforce Islamic law has forced the government to respond to these conditions $^{44}$.

After a long period of not issuing legal products related to the transformation of figh products into a legal formulation, finally, the idea emerged to formulate munakahat fiqh products into law. The legalization process is going very hard, society's pluralism will lead to social jealousy if only the interests of Moslems are accommodated in the law. Initially, the

44 Ratno Lukito, Tradisi Hukum Indonesia, 1st ed. (Yogyakarta: Teras, 2008), 134-135.
Draft Law on Religious Courts was also challenged by factions in the People's Representative Council (DPR).

After the amendments to the Draft Law were made, finally on January 2, 1974, Law no. 1 of 1974 concerning Marriage ${ }^{45}$. To complete the vision and mission of the Marriage Law, an authorized agency was formed for the marriage process. With the issuance of Minister of Religion Regulation No. 11 of 2007 concerning Marriage Registration, the existence of KUA is stronger and legally recognized by the state which generally has a function in controlling the marriage process.

\section{FROM FIQH TO THE STATE: TRANSFORMATION OF FIQH IN STATE LAW}

The post-World War II political feud between the western and eastern blocs also affected the global political atmosphere, because the political hegemony of the western bloc led by the United States brought liberalism and the Soviet Union's eastern bloc with communism was enough to influence the movement of non-aligned countries ${ }^{46}$. The political understanding of the two superpowers also influenced the political system in Indonesia, it is not surprising that historically Indonesian politics at the beginning of independence were influenced by the notions of liberalism and communism, so that Islamic politics promoted by Indonesian Moslems faced stiff competition for positions in the government. Even so, the government does

45 Zuhriah, Peradilan Agama Indonesia. 129.
46 Mudzakkir, "Islam Dan Politik Di Era Kontemporer."32. 
not necessarily ignore the religious law adopted by the majority of Indonesian people. The assumption that Islamic politics describes an authoritarian system of government, the failure of democracy in the Moslem world is associated with the inadequacy of the concept of Islamic government in the field of government ${ }^{47}$. In Islam, the law has been regulated by the Creator, so it does not need a legislative function anymore because Islam already has its source of law. This view, of course, cannot be accepted by countries with a democratic system, as well as by the state of Indonesia.

Indonesia has provided an important solution for the normalization of Islamic law, by taking universal values in Islamic law and adopting them into state law ${ }^{48}$. For Indonesia, the legacy of the Dutch legal system (civil law) is the path of codification of Islamic law into state law through parliament. The fiqh book is an easy way for the government to transform Islamic law, so it cannot be denied that the fiqh book is the most important part in formulating the legal substance with Islamic nuances. The transformation of fiqh in state law has shown developments, one of which is the emergence of Law Number 22 of 1946 which was ratified by Law Number 32 of 1954 which regulates the registration

47 Mansoor Moaddel, "The Study of Islamic Culture and Politics: An Overview and Assessment," Annual Review of Sociology 28, no. 1 (2002): 364-65, https://doi.org/10.1146/annurev.soc.28.110601.14 0928.

48 Mahmudah, "Politik Penerapan Syari'at Islam Dalam Hukum Positif di Indonesia (Pemikiran Mahfud MD)."404. of marriage, divorce and reconciliation. This law then affected the separation of the duties of the penghulu from the head of the court which had previously been one task ${ }^{49}$. Then came Law Number 19 of 1948 concerning the structure and powers of the judiciary and prosecutor's office which states that the religious courts are one of the special courts in Indonesia. However, the existence of the religious courts has not shown a sharp change. Its authority is still mixed with that of the District Court. In addition, there are not many special regulations for Moslems that are used as references in making decisions ${ }^{50}$. There were not many processes of fiqh transformation into law due to the unstable political condition of Indonesia at that time, the rules that were applied were still temporary. In addition to attacks from the Allied forces, Indonesia also faced rebellions that threatened the stability of the nation.

According to Azyumardi Azra and Arskal Salim there are at least four views on Islamic politics in Indonesia; first, the establishment of Islamic groups who want to replace Pancasila with the obligation to implement Islamic law; second, requests from some regions to implement Islamic law; third, the emergence of hardline Moslem groups; fourth, the development of

49 Chamim Tohari, "Transformasi Hukum Islam Dalam Sistem Tata Hukum Di Indonesia," ANALISIS: Jurnal Studi Keislaman 15, no. 2 (2015): 403-432, https://doi.org/10.24042/ajsk.v15i2.730.

50 Nurfaidah Nurfaidah, "Revitalisasi Lembaga Peradilan Agama di Indonesia," Shautut Tarbiyah 15, no. 1 (2009): 120-32, https://doi.org/10.31332/str.v15i1.104. 
Islamic law into state law, this is the development of aspirations to implement sharia ${ }^{51}$. The understanding of state Islamism became volatile when some Moslem figures began to realize that Islamic law was functioning as state law, despite resistance from the Indonesian government at that time. In the end, the government also understands that it is necessary to adopt Islamic law into state law by providing certain limitations, meaning that when the government wants to make civil rules for the Moslem community, the references used are fiqh books and the Moslem scholar thoughts (fatwas).

\section{CONCLUSION}

The process of formalizing Islamic law in Indonesia is still pro and contra, both from non-Moslems and Moslems themselves, this is of course based on differences in attitudes in understanding the relationship between religion and the state. However, in reality, the government with a democratic state system tries to position Islamic law as part of the source of state law, because it cannot be denied that Islamic law is a law that is adhered to and firmly held by Moslems, especially Moslems with traditionalist understanding. The government's challenge in formulating laws that are nuanced with Islamic values is not detrimental to the state, in fact until now Islamic law is still the main reference in building a more comprehensive law. The importance of elaboration between state law, customary law and Islamic law to build a law that is pluralistic in the midst of a pluralistic Indonesian society.

51 Arskal Salim and Azyumardi Azra, Shari'a and Politics in Modern Indonesia (Singapore: Institute of Southeast Asian Studies, 2003), 1-2. 


\section{BIBLIOGRAPHY}

Arifin, Busthanul. Pelembagaan Hukum Islam Di Indonesia: Akar Sejarah, Hambatan, Dan Prospeknya. 1st ed. Jakarta: Gema Insani Press, 1996.

Asikin, Zainal. Mengenal Filsafat Hukum. Yogyakarta: Penerbit Andi, 2020.

Bowen, John R. Islam, Law, and Equality in Indonesia an Anthropology of Public Reasoning. Cambridge, UK; New York, NY: Cambridge University Press, 2003.

Djalil, A. Basiq. Peradilan Agama Di Indonesia: 1st ed. Jakarta: Kencana, 2006.

Fuad, Mahsun. Hukum Islam Indonesia: Dari Nalar Partisipatoris Hingga Emansipatoris. 1st ed. Yogyakarta: LKiS, 2005.

Hadi, Syofyan. "Kekuatan Mengikat Hukum Dalam Perspektif Mazhab Hukum Alam Dan Mazhab Positivisme Hukum.” Legality: Jurnal Ilmiah Hukum 25, no. 1 (July 14, 2018): 88-89. https://doi.org/10.22219/jihl.v25i1.5992.

Hafidh, Ahmad. "Pertarungan Wacana Politik Hukum Islam di Indonesia." Yustisia 3, no. 3 (2014): 19.

Hanafi, Muhammad. "Kedudukan Musyawarah Dan Demokrasi Di Indonesia." Jurnal Cita Hukum 1, no. 2 (April 7, 2016): 235. https://doi.org/10.15408/jch.v1i2.2657.

Hooker, M. H. Adat Law In Modern Indonesia. New York: Oxford University Press, 1978.

Irham, Muhammad. "Perkembangan Politik Hukum Islam pada Masa Klasik dan Kontemporer." Madania: Jurnal Hukum Pidana dan Ketatanegaraan Islam 9, no. 1 (November 16, 2019): 85-98.

Lukito, Ratno. "Islamic Law And Adat Encounter: The Experience Of Indonesia." Institute of Islamic Studies McGiH University, 1997, 35-36.

Tradisi Hukum Indonesia. 1st ed. Yogyakarta: Teras, 2008.

Mahmudah, Siti. "Politik Penerapan Syari'at Islam Dalam Hukum Positif di Indonesia (Pemikiran Mahfud MD)." Al-'Adalah 10, no. 4 (2012): 12.

Manan, Abdul. Aneka Masalah Hukum Perdata Islam Di Indonesia. 1st ed. Jakarta: Kencana, 2006.

—. Dinamika Politik Hukum Di Indonesia. Jakarta: Kencana, 2018.

—. Reformasi Hukum Islam Di Indonesia. Jakarta: Raja Grafindo Persada, 2006.

Mardani. Hukum acara perdata peradilan agama \& mabkamah syar'iyah. Jakarta: Sinar Grafika, 2009.

Mathebula, NE, and PH Munzhedzi. "Trias Politica for Ethical Leadership and Good Governance: Praxis of Checks and Balances in the South African Context." Bangladesh EJournal of Sociology 14, no. 2 (2017): 8.

Menski, Werner. Comparative Law in a Global Context the Legal Systems of Asia and Africa. London: Cambridge University Press, 2006.

Moaddel, Mansoor. "The Study of Islamic Culture and Politics: An Overview and Assessment." Annual Review of Sociology 28, no. 1 (August 2002): 364-65. https://doi.org/10.1146/annurev.soc.28.110601.140928.

Mudzakkir, Amin. "Islam Dan Politik Di Era Kontemporer." Epistemé: Jurnal Pengembangan Ilmu Keislaman 11, no. 1 (June 3, 2016): 31-48. https://doi.org/10.21274/epis.2016.11.1.31-48.

Mujahidin, Akhmad. Aktualisasi Hukum Islam: Tekstual Dan Kontekstual. 1st ed. Pekanbaru: Program Pascasarjana, UIN Suska Riau, 2007.

Najib, Muhammad Ainun. "Politik Hukum Formalisasi Syariat Islam Di Indonesia." In Right: Jurnal Agama dan Hak. Azazi Manusia 6, no. 2 (2017): 19.

Penulis (Palatino Linotype 10pt) $34 \quad$ Penggalan Judul.. (Palatino Linotype 10pt) 
Nasir, Mohamad Abdun. "Wacana Syariat Kontemporer di Barat: Studi Pemikiran Wael B. Hallaq dan M. Barry Hooker." Ulul Albab Jurnal Studi Islam 18, no. 1 (July 31, 2017): 1-4. https://doi.org/10.18860/ua.v18i1.4268.

Nurfaidah, Nurfaidah. "Revitalisasi Lembaga Peradilan Agama di Indonesia." Shautut Tarbiyah 15, no. 1 (May 1, 2009): 120-32. https://doi.org/10.31332/str.v15i1.104.

Pasek Diantha, Made. Metodologi Penelitian Hukum Normatif dalam Justifikasi Teori Hukum. Jakarta: Prenada Media, 2016.

Ratnapala, Suri. Jurisprudence: An Introduction. Leiden: Cambridge University Press, 2009.

Romli, Lili. "Partai Islam dan Pemilih Islam di Indonesia." Jurnal Penelitian Politik 1, no. 1 (August 29, 2016): 29. https://doi.org/10.14203/jpp.v1i1.370.

Rosyadi, A. Rahmat, and H. M. Rais Ahmad. Formalisasi Syariat Islam Dalam Perspektif Tata Hukum Indonesia. 1st ed. Bogor: Ghalia Indonesia, 2006.

S Praja, Juhaya. Perwakafan Di Indonesia. Bandung: Yayasan Piara, 1997.

Salim, Arskal, and Azyumardi Azra. Shari'a and Politics in Modern Indonesia. Singapore: Institute of Southeast Asian Studies, 2003.

Sudiyat, Imam. Asas-Asas Hukum Adat Bekal Pengantar. Yogyakarta: Liberti, 1991.

Sukardja, Ahmad. Piagam Madinah Dan UUD NRI 1945. Jakarta: Sinar Grafika, 2012.

Sunanto, Musyrifah. Sejarah Peradaban Islam Indonesia. Jakarta: RajaGrafindo Persada, 2005.

Thontowi, Jawahir. Islam, Politik Dan Hukum. Yogyakarta: MADYAN Press, 2002.

Tohari, Chamim. "Transformasi Hukum Islam Dalam Sistem Tata Hukum Di Indonesia." Analisis: Jurnal Studi Keislaman 15, no. 2 (2015): 403-32. https://doi.org/10.24042/ajsk.v15i2.730.

Vedi R. Hadiz. "No Turkish Delight: The Impasse of Islamic Party Politics in Indonesia." Southeast Asia Program Publication at Cornell University Press 92 (2011): 1. https://doi.org/10.5728/indonesia.92.0001.

Wahyuni, Sri. "Pengaruh Positivisme Dalam Perkembangan Ilmu Hukum dan Pembangunan Hukum Indonesia." Al-Mazabib: Jurnal Pemikiran Hukum 1, no. 1 (June 1, 2012 ): 3.

Zuhri, LL Saefudin. "Dinamika Islam Politik Dan Islam Kultural di Indonesia." Jurnal IndoIslamika 8, no. 1 (September 29, 2020): 51-66. https://doi.org/10.15408/idi.v8i1.17541.

Zuhriah, Erfaniah. Peradilan Agama Indonesia: Sejarah, Konsep, Dan Praktik Di Pengadilan Agama. Malang: Setara Press, 2014. 